B 4 प91 874

STANFORD UNIVERSITY PUBLICATIONS UNIVERSITY SERIES

MEDICAL SCIENCES

\title{
A Cytological Study of the Kidney Cell in Long Continued Hyperfunction with Relation to Hypertrophy and the Mitochondrial Apparatus
}

\author{
BY \\ LUDWIG A. EMGE \\ Assistant Professor of Obstetrics and Gynecology \\ From the Division of Obstetrics and Gynecology \\ Stanford University Medical School \\ San Francisco
}




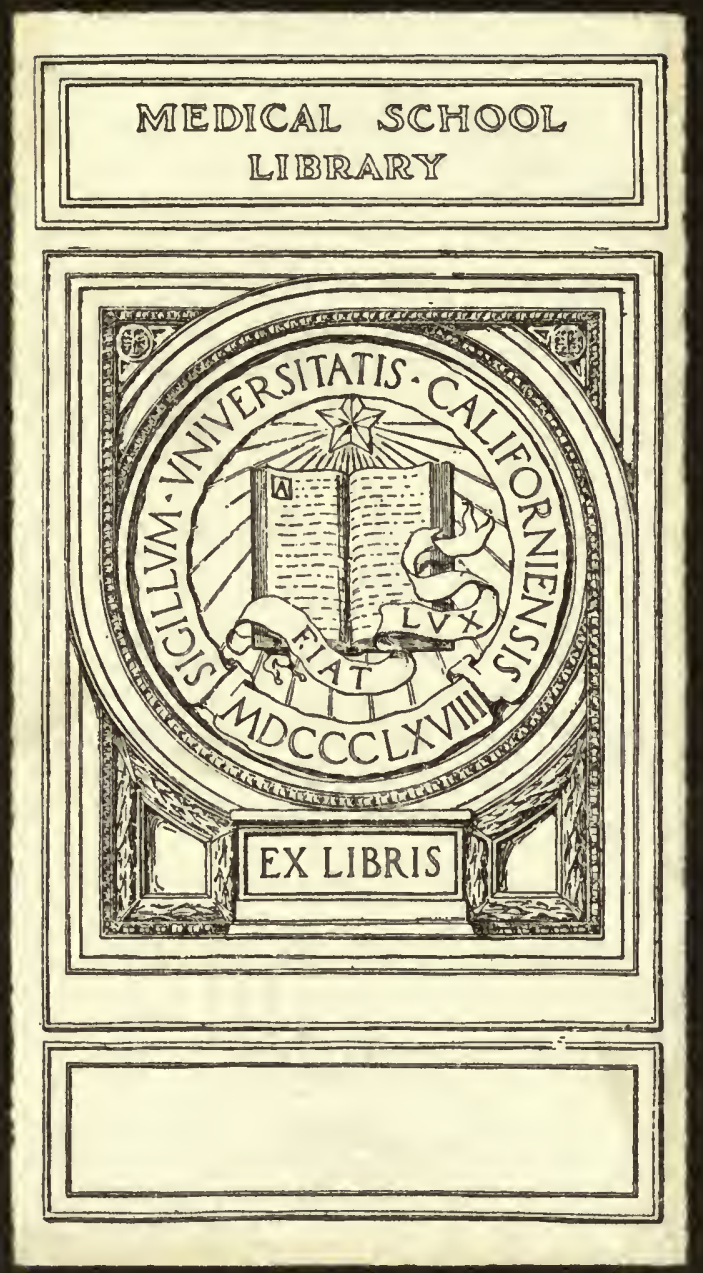


STANFORD UNIVERSITY PUBLICATIONS UNIVERSITY SERIES

MEDICAL SCIENCES

Volume I

NUMBER 2

\title{
A Cytological Study of the Kidney Cell in Long Continued Hyperfunction with Relation to Hypertrophy and the Mitochondrial Apparatus
}

\author{
BY \\ LUDWIG A. EMGE \\ Assistant Professor of Obstetrics and Gynecology \\ From the Division of Obstetrics and Gynecology \\ Stanford University Medical School \\ San Francisco
}




\section{StANFORd University}

Press

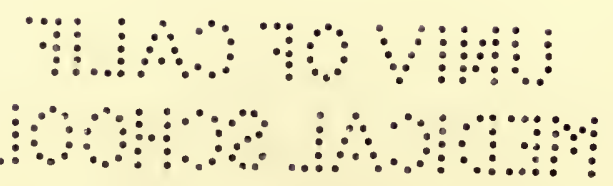




\section{QL872 \\ $E 53$ \\ 1921}

\section{CONTENTS}

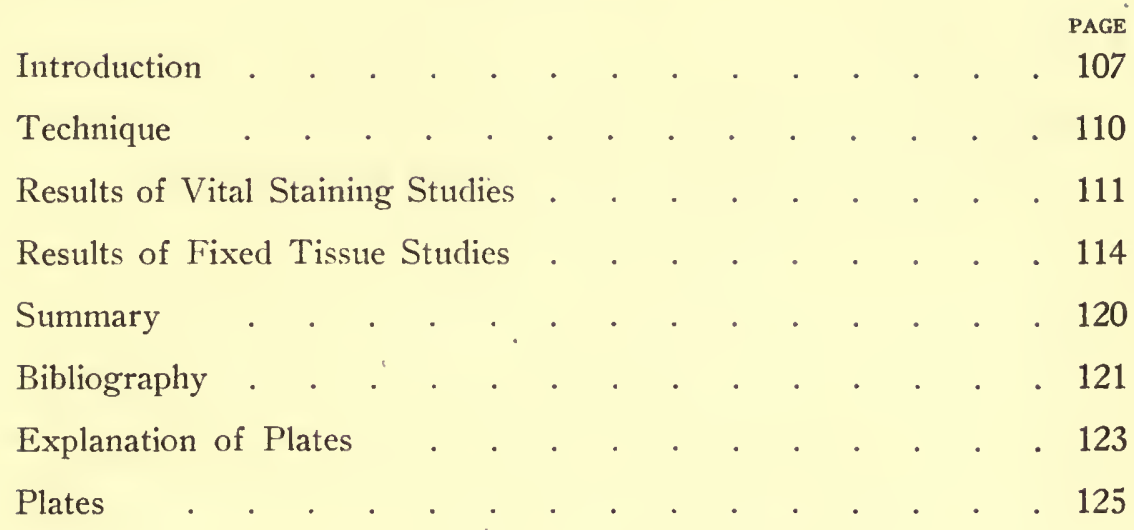


Digitized by the Internet Archive in 2007 with funding from Microsoft Corporation 


\section{A Cytological Study of the Kidney Cell in Long Continued Hyperfunction with Relation to Hypertrophy and the Mitochondrial Apparatus}

Ever since the knowledge of mitochondria had passed the mere descriptive stage numerous attempts have been made to interpret their physiological significance. This investigation was undertaken in order to determine whether wide variations in the duration and degree of experimentally induced renal activity were associated with any demonstrable peculiarities in the mitochondrial content and general cellular structure of the renal tubules. Part of the tissues for this study were obtained through the courtesy of Dr. Addis and Mr. Shevky of the Division of Medicine, who have kindly contributed the life history of the animals used.

\section{NOTE BY T. ADDIS AND A. E. SHEVKY ON THE LIFE HISTORY OF THE MATERIAL DEALT WITH}

(From the Division of Medicine)

There is no direct method by which the "work" of the kidney can be measured, but changes in rate of work may be assumed to be indicated by changes in rate of metabolism. Barcroft(1)* has shown that an increased rate of urea excretion is associated with an increased consumption of oxygen by the kidney, although increases in sodium chloride and water excretion are not accompanied by any appreciable change in gaseous metabolism. On these grounds one would expect to be able to produce renal hypertrophy in intact animals by increasing the work of their kidney by constantly and over a long period giving them large amounts of urea in their food. At least such a result might be expected if the assumption is correct that the increase in size of the remaining kidney after unilateral nephrectomy is due to the additional work it has to perform.

Twenty-four newly-weaned white rats about a month old were divided into two groups as nearly as possible alike in regard to the size, weight, and ancestry of the individuals of which they were composed. Each group was kept in a separate cage of the type described by Robertson(2). The diet used was one shown by Osborne and Mendel(3) to be adequate for growth and maintenance. It contained 15 gms. of lard, 33 gms. of cornstarch, 5 gms. of agar-agar, and 43.5 gms. of powdered milk. In order to facilitate the combination of these ingredients into a homogeneous paste into which urea could be easily incorporated we added $50 \mathrm{cc}$. of whole milk for every 100 gms. of the combined foods. Urea in substance was rubbed in a mortar into that part of the food given to the urea-fed rats, and in order to obviate any possibility of error a little charcoal was added at the same time. For the first two months 5.5 gms. was given with each $100 \mathrm{gms}$. of food, during the third month $8 \mathrm{gms}$., for the fourth and fifth months $11 \mathrm{gms}$., and so on with successive increases until from the 13th to the 16th month, when the experiment was terminated, $17 \mathrm{gms}$. of urea was taken in every $100 \mathrm{gms}$. of food. There

\footnotetext{
* Figures in parenthesis refer to bibliography on pages 121 and 122.
} 
was no limitation of water intake, except that with the idea of straining the ureaconcentrating capacity of the kidney, we removed the water tube from the cage of the urea-fed rats for one hour each day following the giving of fresh food.

There can be no doubt that by these measures we succeeded in making the kidneys of the urea-fed group do much more work than those of the controls. In spite of repeated efforts, however, we cannot give any accurate measure of the difference, since we did not succeed in entirely overcoming the technical difficulties of collecting urine from such small animals. We did find, however, that the ureafed rats took about twice as much water and excreted about twice as much urine. This urine at times contained as much as 10 per cent of urea. The funnel over which the urine ran into the collecting vessel was usually coated with urea crystals. Examination of the feces showed that urea was not excreted by the gastrointestinal tract.

At the end of sixteen months various accidents had reduced the number of rats to eight, four controls and four urea-fed. After a functional test, which will be described below, these rats were killed by bleeding from the carotid artery after very short ether anaesthesia, and the kidneys at once removed and weighed. The results are given in Table I. They fail to show the existence of any hypertrophy.

TABLE I

\section{KIDNEY WEIGHTS OF CONTROL AND UREA-FED RATS}

\section{Controls}

$\begin{array}{ccc}\text { No. } & \begin{array}{c}\text { Kidney Weight } \\ \text { gms. }\end{array} & \begin{array}{c}\text { Body Weight-Alimentary Tract } \\ \text { gms. }\end{array} \\ 1 & 1.37 & 182 \\ 2 & 0.93 & 124 \\ 3 & 1.13 & 132 \\ 4 . & 1.30 & 132\end{array}$

UREA-FED

No. Kidney Weight Body Weight-Alimentary Tract gms. 1.27

1.01

1.40

1.06 gms.

148

115

152

103
Kidney Weight as a

Percentage of Body

Weight-Alimentary Tract per cent.

0.75

0.75

0.85

0.99

Kidney Weight as a

Percentage of Body

Weight-Alimentary Tract per cent.

0.86

0.89

0.93

0.97

On the day before each animal was killed an attempt was made to measure the urea-excreting capacity of the kidneys. In order that both groups might be under the same conditions, no urea was given to the urea group for two days before the experiment. Urea in concentrated solution, $0.5 \mathrm{gms}$. for one pair of rats, and 0.375 for the other three pairs, was injected from a syringe through a fine tube into the stomach. The rat was then placed over a funnel, so that all urine was collected. After three hours the carotids were cut under ether anaesthesia, and the blood collected. The urea content of both blood and urine was determined by the usual urease aeration method. The results are given in Table II. 
TABLE II

UREA-EXCRETING FUNCTION OF CONTROL AND UREA-FED RATS Controls

\begin{tabular}{|c|c|c|c|}
\hline No. & $\begin{array}{c}\text { Urea in One Hour's } \\
\text { Urine }\end{array}$ & $\begin{array}{l}\text { Urea in } 100 \mathrm{cc} \\
\text { Blood }\end{array}$ & $\begin{array}{r}\text { Ratio: Urea in Urine } \\
\text { Urea in Blood }\end{array}$ \\
\hline & mgs. & migs. & \\
\hline 1 & 75 & 165 & 0.45 \\
\hline 2 & 48 & 186 & 0.26 \\
\hline 3 & 34 & 76 & 0.34 \\
\hline 4 & 8 & 132 & 0.06 \\
\hline \multicolumn{4}{|c|}{ UREA-FED } \\
\hline No. & $\begin{array}{c}\text { Urea in One Hour's } \\
\text { Urine }\end{array}$ & $\begin{array}{c}\text { Urea in } 100 \mathrm{cc} \\
\text { Blood }\end{array}$ & $\begin{array}{r}\text { Ratio: Urea in Urine } \\
\text { Urea in Blood }\end{array}$ \\
\hline & mgs. & mgs. & \\
\hline 5 & 85 & 102 & 0.83 \\
\hline 6 & 44 & 93 & 0.47 \\
\hline 7 & 64 & 140 & 0.46 \\
\hline 8 & 58 & 60 & 0.97 \\
\hline
\end{tabular}

The higher rate of urea excretion in spite of the lower level of blood urea concentration in the urea-fed rats seems to indicate a greater facility in the excretion of urea, in spite of the absence of any appreciable increase in the size of their kidneys. But the number of experiments is much too small to allow for any definite conclusion.

The two groups of animals whose physiological history has been described by Addis and Shevky were supplemented with another two groups of white rats similar in age and weight. One group was fed general food and the other was given urea food as noted in the life history of the tissues of the first two groups. After several days' feeding, the first pair, ureafed and control, was killed. Then within two weeks a pair was killed every other day. The idea was to obtain tissues for study of possible early changes in the renal cellular structure produced by urea feeding for a comparison with tissues from kidneys in a normal state of activity.

There were, therefore, four distinct groups available for comparative study; the first, composed of kidneys which since early youth had been subjected to a constant strain in the excretion of large amounts of urea; the second, a group which had been fed a similar diet without urea but had been given a single dose of urea just before death; the third, a group which was fed urea over a period of from two to fourteen days before death; and the fourth, a group fed on ordinary diet which received no urea whatsoever. 


\section{TECHNIQUE}

Owing to the fact that the kidneys had to be weighed for reasons explained in the above life history, fixation by arterial injection could not be practiced. This would in any case have been impracticable since it would not have permitted vital studies.

As fixing agents Bensley's(4) formalin-zenker, Regaud's(5) neutral formalin-bichromate, and Kolster's(6) chromalum and fluorchrome mixtures were used. Controls were also fixed in chemically pure, freshly neutralized 10 per cent formaldehyde. It was impossible to obtain osmic acid at the time of this investigation (1918). Tissues in pieces of $2 \mathrm{~mm}$. thickness were fixed in these agents from one to three days and then chromicized from three to nine days. A temperature of about body heat was maintained throughout the period of fixation. The fluids were changed daily. The fixed material was cleared with either cedar oil, bergamot oil, or xylol. I have found practically no difference in the shrinkage of the tissues with either of the three, and therefore have used xylol in preference as it is the fastest and least expensive of all clearing agents. Paraffin, $60^{\circ}$, was used as the embedding medium. Sections were cut serially and about $5 \mu$ thick. Altmann's(7) anilin-fuchsin picric acid method in its original form and as modified by Cowdry(8) and Galeotti(9), Bensley`s(4) anilin-acid-fuchsin methyl green, Beṇsley's(4) copper-chromehematoxylin and Heidenhain's iron-hematoxylin were used. Simple conventional stains were employed as a check on the general picture. Apparently it is not necessary to use osmic acid to obtain good fuchsin pictures. Such simple bichromate mixtures as mentioned above will preserve mitochondria excellently and allow good staining results.

Among the fixatives the formalin-zenker and the neutral formalin bichromate mixtures with a period of chromization have given by far the best results. Of the staining methods the anilin-acid-fuchsin methods are quicker but otherwise in no way superior to the other methods mentioned.

Fresh tissues were studied in a normal saline solution of $1: 10,000$ Janus green $\beta$. Arnold's(10) neutral red and methylene blue were used in several control animals. Janus green studies of renal tissues are very difficult. First of all, the dye seems to penetrate very slowly, and one is therefore not certain whether the mitochondria have not changed in appearance by the time they stand out plainly; secondly, mitochondria are usually massed so densely in the convoluted tubules that a clear picture is very rarely obtained; thirdly, in order to obtain thin enough pieces of tissue one must either tease them out or cut them with the freezing microtome. Either method furnishes ground for controversy. It seemed to me, however, that sections cut with a good. freezing outfit are preferable to teased-out tissues. 


\section{Results of Vital Staining Studies}

Nothing remarkable was found in the vital staining studies. It was at once plain that in spite of the poor penetration of the dye, the mitochondria of the convoluted apparatus by far outnumbered those of the remaining tubular structure. Comparing controls to urea-fed rats of the first group, there was no striking difference in the mitochondrial picture in general. In all tissues studied the impression was gained that in the control rats the mitochondria of the convoluted tubes were arranged in distinct, closely packed stout rods or in bands of medium-size granules, which extended about two-thirds into the cell and which were most numerous near the base. In the collecting apparatus the finer, less numerous granular mitochondria were distributed throughout the cell, leaving a clear space around the nucleus. In the large tubules of Bellini the stout rodlike form appeared again, but the number was few, and I judged that more than half of the cells were mitochondria-free. In the urea-fed rats the only difference in the mitochondrial picture was that the granular form in general prevailed, but position and arrangement seemed to be the same as in the controls. At any rate, no such morphological differences existed as would warrant inferences as to differences in secretory activity in the proximal convoluted tubules of the four groups of kidneys.

The use of vital color reactions to solve the secretory problem of the kidneys dates back to 1874, when Heidenhain(11) and Neisser first injected dyestuffs into animals and found them in the convoluted tubules, while the glomeruli and capsules were free from color materials. This work in general has been substantiated by a number of investigators. Since the exhaustive histochemical studies of Leschke(12), confirmed by Oliver(13), it seems more clear than ever that urea and perhaps other urinary solids are secreted (or excreted) in the convoluted apparatus, while the glomerular apparatus is primarily concerned with the secretion of practically solid-free fluids. The difficulty enters when one tries to obtain evidence by vital dye studies as to whether the mitochondrial apparatus is directly concerned with the secretory mechanism of the cell of the convoluted tubule. One must not forget that most of the dyestuffs used in histological methods are of colloidal nature, and consequently when seen in cells that secrete substances crystalloid in nature they cannot be used as an absolute criterion or parallel. The presence of dye materials in the renal cells brought there by the blood or lymph stream must be considered a physical rather than a chemical reaction, as was brought out by Suzuki(14) working in Aschoff's laboratories. He found that the dye appeared in the urine long before the granular structures of the convoluted tubules, showed any signs of staining. Carmine in various. concentrations was used and at an "early stage of excretion" many finely granular carmine casts were present in the collecting tubules. Suzuki 
states that the presence of these granules does not point to carminestained secretory granules derived from the epithelium of the convoluted tubules, but rather to a product of precipitation of the dyestuff in solution, which is only in part passed through the convoluted tubules, while some of it passes through the glomerular apparatus. He calls attention to the fact that by pushing the carmine injections there is a gradual accumulation of dyestuff in the renal epithelium which ultimately leads to staining of the true cell granules. The latter, therefore, must be sharply differentiated from carmine granules. His results lead him to believe that the carmine-absorbing granules have nothing to do with the actual secretion of the dye material.

The objection that might be raised is that carmine is not a specific vital dye for mitochondria. Nevertheless the fundamental result remains unchanged. Many investigators are in accord that the striations of the convoluted tubules of the kidney are homogeneous rods when seen in fresh tissues, but become granular in appearance under various conditions. Some have considered this a true secretory phenomenon, others an artefact. Arnold(15) thinks that the individual granules of the living renal epithelium are pre-existing in the rods and joined together by segments. In my studies I have repeated Arnold's neutral red and methylene blue method, and I am convinced that such a differentiation can be obtained. The granules are stained red and the segments blue. There are, however, certain objections. First of all, neither dye is specific for mitochondria; secondly, in order to obtain a good differentiation of the binding segments penetration has to be prolonged, and it is well known that mitochondrial rods will break up slowly into granules if they are exposed to changes in temperature or to substances poisonous to tissues. This was shown by Lewis and Lewis(16) in tissue cultures, by Suzuki in his carmine injections, and in various pathological conditions by Ophüls(17), Takaki(18), Israel(19), Burmeister(20), Landsteiner(21), Störk(22), Pfister(23), and others.

While Janus green is considered a specific vital dye for mitochondria, it is not a very satisfactory dye for the kidney as it penetrates very slowly, even under the most favorable conditions, as on a warming stage. It has the tendency to bring out a granular rather than a rodlike structure, and the observation made here that the granular structure was seen more often in the urea-fed rats may be the result of various circumstances. If no warming stage is used the difference in temperature alone may be sufficient to produce granular dissolution. If a stage is employed such changes in osmosis as may be produced by evaporation may create granular changes. Césa-Bianchi(24) has protested against the assumption of pre-existing granules on the basis that unstained fresh tissues have solid rods. He maintains that the granular picture is created by fixation or by 
the influence of foreign substances. It did occur to me that by polarization such a question could be settled. Unfortunately, at the time of this investigation this chance was overlooked.

The only result in this part of the investigation that can be offered as a fact is, that in Janus green studies the tubules which were proven by Leschke(12) and Oliver (13) to give off urea also are the ones that have the greatest abundance of mitochondria, and that the tubules which Suzuki(14) considered the resorption tubules, have no or very little mitochondrial structure. But that there is a difference in vital staining reaction between the mitochondria of kidneys after long-continued or acute strain in urea excretion, as compared with those acting normally, cannot be asserted.

Since in some of the first tissues studied vitally there were seen spherical, highly refractile bodies of various sizes apart from mitochondria, Sudan III and scarlet r. were employed in the remaining tissues after a Janus green penetration had been obtained. These round bodies stained brilliantly and instantaneously with the so-called fat dyes which did not influence the green-stained mitochondria. The arrangement of these bodies was irregular and without any apparent similarity in neighboring cells in the entire group of tissues studied. That is to say, they were as numerous in the controls as in the urea-fed rats of the first and second group. From this I judge that normally there is free fat, or a substance related to fat, in the cells of the kidney of white rats. At no time did these round bodies stain with Janus green, and this dye is specific for mitochondria. It is obvious that these bodies are not aberrant physical forms of mitochondria. In the fixed sections similar, or perhaps the same, structures have been seen by several investigators, and explanations have been offered which point out that these bodies may be concerned with secretion. Heidenhain(25), Hoeber and Koenigsberg(26), Van der Stricht(27), and Gurwitsch(28) have described intracellular vacuoles of various positions and sizes. These vacuoles were thought to act as collectors of secretory materials. Gross(29) and Hirsch(30) were not able to confirm the presence of these vacuoles. Retzius(31) observed these structures but did not think them vacuoles. He rather interpreted them as true droplets of secretion. In these droplets he saw very fine granules connected by fine threads. At a time when the cell appeared high and the brush border had disappeared these droplets were supposed to be expelled into the lumen of the tubule.

In my fixed sections the position and sizes of the occasional "vacuoles" observed seemed to correspond in location to the fat bodies described above. At no time could I find sufficient proof that in the vitally stained tissues fat droplets were similar in arrangement or staining to mitochondria. Nevertheless, it may be possible that these substances are 
derived from mitochondria as pointed out by Ophüls (17), but if that is so it is evident that some change has occurred involving radical alteration in the staining affinity of the mitochondrial substance.

\section{Results of Fixed Tissue Studies}

In studying the low-power picture the cortex stands out massively on account of the mitochondrial richness of its tubules. This picture varies in its color intensity with the variations in mitochondrial density and also with the variations in fixing agents. Nevertheless, the color coefficient between medulla and cortex remains stationary. On viewing the cortex, even with the lowest power, one can easily distinguish the proximal convoluted tubules on account of their greater staining intensity. Fig. 1 gives a fair demonstration of the difference in color density between proximal and other tubules of the cortex.

In comparing sections from the four groups of kidneys differences could always be found, but further study invariably showed that such differences also existed within the individual group and therefore could not be used in differentiating the groups. Only the study of serial sections can protect against unwarranted conclusions. As a demonstration I wish to cite an observation which, without serial study, would easily have led to faulty inferences, if coincidence should have thrown the observations mostly into one group of tissues.

In the studies of the group described by Dr. Addis a peculiar picture of divisional action of groups of convoluted tubules is observed, if one may use this term for the sake of simplicity (see Figs. 2 and 3). It is at once apparent that in some tissues entire groups of convoluted tubules with their connecting segments (Schaltstücke) stand out very plainly by virtue of their mitochondrial concentration in contrast to other neighboring groups, which have less and fainter staining, but otherwise similar appearing mitochondria. A casual observer might be easily misled by such a picture. In this study it seemed at first that such a grouping was more often seen in the tissues of the rats which had undergone prolonged urea feeding. But the study of a large number of sections from all the groups dissipated this impression. All kidneys showed this peculiarity in some part or other of their structure. While this phenomenon does not give any help in differentiating the kidneys of urea-fed from control rats, it is of interest in relation to Lindemann's (32) hypothesis of a division of labor in the individual kidney in which certain groups of tubules supposedly are allowed to rest while others are active. At any rate it illustrates the fallacies of drawing conclusions from sections which are not representative of the entire organ.

The absence of any appreciable increase in the weight of the kidneys in Group I, which had been fed urea over a long period, precluded the existence of any gross difference in the number and size of the cells as 
compared with the second group. Yet, it was thought possible that there might be a constant difference in the minute structural arrangement within the cell, and a careful comparison was therefore made in order to determine whether such qualitative distinctions might not be associated with the various degrees in urea.feeding, especially as compared with the group which did not receive any urea at all.

In studying the general cell picture one finds that the height of the cell of the proximal convoluted tubule is fairly constant, and such variations as exist seem to depend somewhat on the mitochrondial content of the cell. If the content is low the icell cupola is high and the lumen is very narrow (see Figs. 6 and 7 ). This is especially true when the mitochondrial apparatus is in a state of advanced granular dissolution (see Fig. 8). With the increase in the numerical content of the mitochondria the cell becomes somewhat lower. The cell cupola at once becomes clear and the plasma just at the base becomes transparent. The more definitely the mitochondrial apparatus assumes the "bâtonné" arrangement the more apparent becomes this decrease in cellular height (see Fig. 11). With this go certain variations in configuration and width of the lumen. When the mitochondrial content is low and the plasma is dense throughout the cell the lumen is narrowest and somewhat stellate in character (see Figs. 6 and 7). As soon as the granular structures become definite in their arrangement, the lumen widens and only fine strands of protoplasmic material bridge the lumen in an irregular fashion (see Fig. 12).

In comparing the cells of the tubular structure of the kidneys of the various groups it was at once apparent that those from animals fed urea did not show any evidence of a distinctive increase in the size of the cells of any part of the tubular apparatus. In any kidney from any group it was possible to find the lesser degrees in variations in the size of individual cells which have been discussed above (see Figs. 9 and 10). One may therefore conclude that urea feeding does not stimulate hypertrophy of the cell of the kidney even if such feeding is carried to the extreme by extending it over the life period of the animal in question.

Also the appearance of the brush border does not offer any conclusive evidence that it is influenced in any way by the forced feeding of urea. I cannot agree with those writers who think that the variations in the morphological appearance of the brush border are indicative of phases in the secretory process. By some it is claimed that it gradually rises, due to cellular pressure, until it is thrown off to allow the secretory material to enter the lumen. Others do not share this view, and consider the passage of secretion material as a true secretion phenomenon. Especially Sauer (33) in his earlier studies opposed the former idea, since he always found a typically striated appearance of the brush border at any stage of secretion. Of late Kolster(6) once more has drawn attention to 
the brush border. He believes that in what he calls the "resting stage" (when the cells are high and the lumen narrow) the brush border is low and possesses a very distinct striation, while in the active stage the brush border increases in thickness and appears indistinct in its markings.

Whatever may be the significance and affiliation of the brush border with other cell structures, it undoubtedly is one of the finest architectural tissue structures and therefore exposed to the greatest variations in fixing artefacts. In these studies this was confirmed by the careful examination of pieces of tissue where for unknown reasons penetration had lagged. Here, in sections cut deeper in the piece of the tissue, the brush border was severely damaged and often had a "glued-together" appearance. Such a condition may easily lead to misinterpretations. And as coincidence occasionally will produce such an artefact in a group of tubules where the mitochondrial content is low, it is easy to associate the two and regard them, as Kolster(6) does, as indicative of a distinct phase in secretion. I admit that there are differences in the thickness of the brush border, and this is regulated somehow by the condition of the plasma of the cell of the convoluted tubule, since the brush border appears clearest whenever the cell cupola is most transparent. This is true of vitally stained as well as fixed tissues. Just because it is so, it may be an optical illusion, because of the fact that more light is permitted to strike the brush border from all sides under this condition, while it can strike the brush border only from three sides when the plasma is dense, and therefore the striations may not be seen as clearly. Consequently the distinctness of the brush border striations must vary normally. The actual height of the brush border varies very little within the individual section of the proximal tubule. In well fixed tissues $I$ have never seen a place where the brush border was shed or being lifted off. I am unable to present any photomicrographic proof for this statement, as I have not succeeded in taking a picture which will show the finer inner cell structure clearly and at the same time do justice to the brush border. In fact, with the mitochondrial stains brush-border photography is almost impossible.

Occasionally one sees granular structures in the brush border (see Figs. 4, 8, 12). They take the same stain as do the granular structures of the cell itself. These granular bodies, which vary greatly in size and which are commonly larger than mitochondria when there is a dissolution of the rods, may constitute a direct or indirect product of the mitochondrial apparatus and merely represent a physical combination of more than one of the large granules seen in the cell cupola in certain phases in the life cycle of the cell of the convoluted tubule, or, in fact, in any of the cells of the tubular structure in general (see Fig. 8). Only occasionally are similar granules seen in the cell lumen or within castlike formations. Also, here they do not differ morphologically from the cell 
granules. To call them mitochondrial secretion products offhand is open to criticism, since we have not accepted it as an absolute fact that the mitochondria of the kidney enter into the secretory role.

When we now compare the various groups of the kidneys studied in reference to the appearance of their brush borders, it again must be admitted that there is no proof that this structure is influenced in any way by urea feeding. Such variations as may be found can be demonstrated within each individual group, and therefore must be considered as a normal variation of the brush-border picture.

In the studies of the mitochondrial apparatus of the kidney of the white rat certain generalities have been agreed upon by all investigators. Upon general survey one is always impressed with the intense staining of the proximal and to a lesser degree of the distal convoluted tubules. In the proximal tubules the mitochondrial apparatus is very distinct and consists of true rods or of varying degrees of granular dissolution of these rods. The mitochondrial numerical concentration is higher here than in other segments of the tubule. Also the affinity of the individual granule for certain stains is greater because the granule is larger here than in any other segment (see Figs. 4 and 5). Both conditions explain the color prominence of the proximal and, to a lesser degree, of the distal convoluted tubules. The greater staining affinity is aparently of purely physical and not chemical origin, this assumption being based on a greater concentration of the mitochondrial material in one unit. In the medial and distal parts of the proximal tubules the mitochondrial structure is less dense and the granular dissolution more pronounced. The descending limb of the loop of Henle is very poor in granules and occasionally appears free from them, so that it is hard to recognize them with mitochondrial stains. the chainlike or rodlike arrangement of the mitochondria, which is so typical of the proximal convoluted tubules, is suggested again in the mitochondrial arrangement of the ascending limb of Henle's loop. But here the granules are very much more scarce, smaller and quite irregularly arranged. Especially in the cell cupola this irregular arrangement is apparent and gives to it a peculiar, loose appearance. The distal convoluted tubules are similar to the proximal convoluted tubules, except that the mitochondrial apparatus is less dense and the cell is lower in general. The epithelium of the collecting tubule is very low and the grantular structures fine and well scattered (see Figs. 13 and 14).

Studying on this general basis the kidneys of the rats which had undergone prolonged urea feeding, and comparing the results with those of the rats of the other three groups, no essential difference in the mitochondrial apparatus can be detected. Also in this group the intensely staining mitochondria of the proximal convoluted tubules dominate the picture (see Figs. 4, 5, 9, 10, 12). But on careful study one is at once 
impressed with the want of constancy in the appearance of the mitochondria in different or even in the same microscopic sections from the same kidney. This holds good also in the other groups. Serial sections prove that in every kidney distinct variations in the structural picture of the mitochondria of the same proximal convoluted tubule are always present; that is to say, the variations depend upon the level at which the section is cut. There is always a gradual transition in the shape of the mitochondrial structure from one segment of the tubule to the other. Even within the central limit of the segments studied such variations are present. Then again neighboring segments of the same type but of different tubular units may vary distinctly in the structural arrangement of their mitochondria as to size, number, and shape. But such variations cannot be the result of urea feeding, since they are also found in the kidneys of the rats that were not fed any urea at all. There are about as many variations as there are kidneys studied, and I am afraid one could carry the descriptions of the various combinations of these on to the infinite. True enough, on a general quick survey of the sections of the group that received no urea, the picture of the kidney of the white rat described for the normal, holds good, but when it comes to comparing even neighboring sections of the same tubular group, variations are also found here at once. For instance, there is a distinct difference in the granular dissolution in Figs. 8 and 12, which are sections from the controls of the first group. But the same is true of the kidneys of the rats fed urea over a long period (see Figs. 6, 9, 10). Then again the dogmatic picture which has been described for the normal is represented by Fig. 11, but it is a picture of the proximal convoluted tubule from a kidney exposed to a long urea strain. Here the beautiful "bâtonné" arrangement is very apparent and dominates the optical impression received. These instances merely illustrate the point raised.

In comparing the individual mitochondrial granules of the various groups no hypertrophy was observed in those where urea had been fed, and when compared to controls from the first and second group no numerical increase could be established. It is impossible to segregate the various groups of rats by the appearance of their mitochondrial apparatus. Granular dissolution or breaking up of the solid rods is not any more a characteristic of the urea kidneys than of the control kidneys (compare Figs. 6 and 7,9 and 12). Nor is the size of the granules produced during dissolution any indication that the mitochondrial apparatus of the proximal convoluted tubules is in any way affected by increased urea secretion, since the same picture is found in controls that did not receive any urea whatsoever. If we pay attention to the qualitative difference in staining it can be stated that there is none except for the usual normal variation. 
The picture of the mitochondrial structure of the other tubular segments corresponds in general to those described for the normal with certain small variations under ordinary conditions. The glomeruli and their capsules are practically free from mitochondria in the kidney under normal activity, and urea feeding does not bring on an increase (see Figs. 15 and 16). There are no indications anywhere in the tissues that pathological changes had been produced by urea feeding.

A number of observers have ascribed a secretory role to the mitochondria of the kidney, such conclusion being based on animal experimentation. For instance, during hibernation Ferrata (34), Disse(35), and Monti(36) found the following changes from the normal under ordinary circumstances: the lumina of the convoluted tubules are narrow and the epithelium is not sharply outlined but markedly granular. Near the base the granules assume a regular chainlike arrangement, while the inner and less dense part of the cell is traversed by fine threads. When secretion sets in, this latter part of the cell becomes quite transparent, bulges toward the lumen and granules replace the threads. This appearance was considered a storage of granules supposedly characteristic for a prophase of secretion.

Also Takaki(18), working with starvation and dry feeding, and Kolster(6), using similar methods together with sodium chloride injections, concluded that mitochondria have a definite place in the secretory process of the kidney. Their investigations tend to divide the stages of secretion according to the appearance and arrangement of mitochondria. Their findings have been confirmed by Schultze(37). It is of greatest importance that Regaud(38), after most exhaustive studies, concluded that all the various types of granules, rods, and filaments described under different names belong to the same group, namely, mitochondria, and that they varied in their appearance according to a number of conditions among which were changes in the secretory activity of the cell. It was Simon(39), Retterer(40), and Henschen(41), and to some degree Dumas(42), Mayer and Rathery (43), who substantiated Regaud's conclusion by further experimental work. Nevertheless, the changes mentioned have been thought to be artefacts by Prenant(44), Policard(45), Levi(46), and Ciaccio(47).

I cannot agree with the latter, since I feel certain that the mitochondrial play seen in these studies, and of which photomicrographs are presented here, is not the result of variations in fixation. It is true that different fixations (fixing agents) of pieces from the same tissue will show slight differences in the appearance of the individual mitochondrial unit, but aside from this the variations observed within one piece are constant for that fixation, and correspond to the variations in pieces fixed differ- 
ently, after one has allowed for the deduction of such changes as are produced by the fixing agents generally.

Leschke, and later, Oliver, found that urea was secreted in the proximal convoluted tubules. The mitochondrial concentration is highest in this part of the tubular apparatus, and the mitochondrial changes, which by many have been thought to be of secretory importance, are also here most pronounced. It is, therefore, only natural to attempt to link together these observations. But the studies cited here lead me to believe that urea feeding of various degrees does not influence beyond normal variations the physical appearance of the mitochondrial apparatus of the kidney of the white rat in general and of its proximal convoluted tubules in particular.

\section{SUMMARY}

The result of an anatomical comparison between the kidneys of white rats on a mixed diet, calling for no unusual renal activity, and the kidneys of rats which for prolonged or brief periods of time had undergone a markedly abnormal strain in the excretion of large amounts of urea, may be summed up as follows:

1. Prolonged urea feeding led to no increase in the size of the cells of any part of the glomerulo-tubular apparatus.

2. Neither a prolonged nor a brief increase in urea excretion had any observable effect on the appearance of the brush border.

3. A careful study of the mitochondrial apparatus of the kidney failed to show that variations in the rate of urea excretion during life were associated with any change in the number, size or position of the mitochondria.

I take occasion to express my sincere appreciation to Dr. T. Addis for his most helpful suggestions in editing this paper, to Miss Ella Wing for her splendid help in the technical work, and to Dr. F. E. Blaisdell for his kind advice in photographic difficulties.

Stanford University Hospital, San Francisco 


\section{BIBLIOGRAPHY}

1. Barcroft, J., and Brodie, T. G.: Journal of Physiol., 33, 52, 1905-6. London.

2. Robertson, T. B., and Ray, L. A.: Journal of Biol. Chem., 24, 347, 1916.

3. Osborne, T. B., and Mendel, L. B.: Journal of Biol. Chem., 17, 401, 1914.

4. Bensley, R. R.: Amer. Jour. Anat., 12, 297, 1911.

5. Regaud, C.: Arch. d'Anat. micr., 11, 291, 1910.

6. Kolster, R.: Ziegler's Beiträge, 51, 209, 1911.

7. Altmann, R.: “Die Elementarorganismen, etc.," p. 27. Leipzig, Veit Co., 1890.

8. Cowdry, E. V.: Contributions to Embryology, Carnegie Institution, Washington. No. 11, p. 27, 1916.

9. Galeotti, G.: Intern. Mtschrft. f. Anat. u. Phys., 12, 461, 1895.

10. Arnold, J.: Virchow's Archiv., 169, 1, 1902.

11. Heidenhain, R.: Arch. f. micr. Anat., 10, 1, 1874.

12. Leschke, Erich :

(1) l'ter Kongress für innere Medizin, Wiesbaden, 1914, p. 635.

(2) Zeitschr. f. Klin. Medizin, 81, 14, 1914-15.

13. Oliver, Jean: Jour, of Experimental Medicine, 23, 301, 1916.

14. Suzuki, T.: "Zur Morphologie d. Nierensekretion." Jena, 1912, Gustav Fischer.

15. Arnold, J.: "U'eber Plasmastrukturen." Jena, 1914, Gustav Fischer.

16. Lewis, M. R., and W. H.: Am, Jour. of Anat., 17, 339, 1915.

17. Ophüls, W.: Proc. Soc. Exp. Biol., 4, 135, 1907.

18. Takaki, K.: Arch. f, mikr. Anat., 70, 245, 1907.

19. Israel, O.: Virchow's Arch., 123, 310, 1891.

20. Burmeister, Th.: Virchow's Arch., 137, 405, 1894.

21. Landsteiner, K.:

(1) Wiener klin. Wochschft., 41, 1904.

(2) Ziegler's Beitraege, 33, 157, 1903.

22. Störk, O.: Sitzbr. d. k. Akad. d. Wissenschaften, Wier., 115, Abt. 3, 1906.

23. Pfister, M.: Ziegler's Beitraege, Arnold's Festschrift, 37, Suppl. 7, p. 525, 1905.

24. Césa-Bínchi, D.: Intern. Mtschrft. f. Anat. u. Phys., 27, 89, 1910.

25. Heidenhain, M.: "Plasma und Zelle," Jena, G. Fischer, 1911.

26. Hoeber, R., and Koenigsberg, A.: Pfueger's Arch., 68, 323, 1905.

27. Van der Stricht, O.: Annal. d. l. Soc. d. Med. Gent., 1892, Reprint.

28. Gurwitsch, A.: Pflüger's Arch., 91, 71, 1902.

29. Gross, W.: Ziegler's Beitr., 51, 528, 1911.

30. Hirsch, C.: Anat. Hefte, 41, 131, 1910.

31. Retzius, G.: Biologische Untersuchungen, 17, 53, 1911.

32. Lindemann, W.: Ergebn. d. Phys., 14, 643, 1914.

33. Sauer, H.: Arch. f. mikr. Anat., 46, 109, 1895. 
34. Ferrata, A.: Arch. ital. Anat. e embr., 4, 505, 1905 (see Schwalbe's Jahresberichte for 1905, p. 505).

35. Disse, J.: Anat. Hefte, 2, 143, 1892.

36. Monti, R., and A.: Mem. let. ital. d. Istitut. Lomb. Pavia, 14, 82, 1900.

37. Schultze, O.: Anat. Anz., 38, 257, 1911.

38. Regaud, Cl.:

(1) C. R. Soc. Biol., 64, 1145, 1908.

(2) C. R. Soc. Bioh., 65, 206, 1908.

39. Simon, Ch.: Compt. Rend. Soc. Biol., Paris, 50, 443, 1898.

40. Retterer, E.: Compt. Rend. Sac, Biol., Paris, 60, 560 and 611, 1906.

41. Henschen, F.: Anat. Hefte, 26, 575, 1904.

42. Ribadeau-Dumas, L.: Compt. Rend. Soc. Biol., Paris, 54, 484, 1902.

43. Mayer, A., and Rathery, F.: J.d. l'Anat. et de Phys., 45, 321, 1909.

44. Prenaint, A.: Compt. Rend. Soc. Biol., Paris, 59, 218, 1905.

45. Policard, J.: “Rev. générale d'histolog." p. 431, Masson, 1908.

46. Levi, G.: Arch. ital. di Anat. e di Embr., 10, 168, 1911.

47. Ciaccio, C.: Centralbl. f. allg. Path., 55, 131, 1913. 


\section{Explanition of Plates}

Technical Remarks: All photographs were taken with a Zeiss microscope on Cramer isochromatic plates. For illumination a 4-5 amp. Leitz arc-light filtered with a single potassimm bichromate (Orth) screen was used. The ocular used for all pictures is No. 4, the objective for "low power" is No. 3, for "high power" No. 6, and for "oil-immersion" No. 1/12 apochromatic. The difference in size of corresponding structures in different pictures photographed with the same microscopical magnification is due to slight differences in the length of the bellows of the camera, which has to be varied according to various circumstances. For printing Azo "E and F hard" were used.

All preparations reproduced here were fixed in either Regaud's or Bensley's formalin bichromate nixtures, and stained with a modified "Altmann anilin fuchsin," in which the destaining of the plasma with picric acid had been carried over the usual point. This assures a high contrast for mitochondria. Only Figure 2 is from a copper-chrome-hematoxylin preparation.

Figure 1, low power, urea fed just before the death. The proximal convoluted tubules stand out by virtue of the greater density of the mitochondrial content. This is the typical low power picture.

Figure 2, low power, urea fed just before the death, and Figure 3. low power, urea fed over a long period. In contradistinction to Figure 1, Figures 2 and 3 show a distinct localized staining reaction of certain tubular groups. while the neighboring and otherwise same structures remain faint in outline. In the left-hand corner of Figure 3 the usnal picture is approached again. The localized staining reaction is due to the greater mitochondrial concentration in this region and occurs in any kidney uncler ordinary circumstances. Figure 3 is somewhat obscured by faulty illumination.

Figure 1, high power, urea fed just before death, and Figure 5, high power, no urea fed, represent the usual dogmatic picture of the mitochondrial distribution in the kidney of the white rat under ordinary circumstances. That one dose of urea has no influence on the mitochondrial apparatus is seen in Figure 1 by the unchanged appearance and distribution of the granules. The proximal convoluted tubules stand out very distinctly. The lumen is narrow. The brush border cannot be distinguished, for reasons explained elsewhere. The distal convoluted tubules, connecting segments (Schaltstück) and the limbs of Henle's loop are distinguished easily. The descending limb of the latter is free from mitochondria. The distal convoluted tubules (segment intermédiaire, Schweigger-Seidel's Zwischenstück) are recognized by the wider lumen 
and the fewer mitochondria. A. Glomerulus. B. Proximal convoluted tubule. C. Distal convoluted tubule. D. Descending limb of H. L. E. Ascending limb of H. L. If. Connecting segments.

Figure 6, high power, urea fed during entire length of life, and Figure $\%$, oil inmersion, no urea fed at all, show the end stage in granular dissolution. There is no difference in size, appearance and arrangement of the granules. The lumina of the tubules (proximal) are narrow and the cells are high in either urea-fed and regular-diet animal. In the latter the chainlike arrangement of the granules is still preserved. This configuration has been described as the end stage of secretion.

Figure 8, high power, urea fed just before death, and Figure 9, oil immersion, urea fed during the entire life, apparently represent distinctive and different types of granular dissolution. But comparing Figure 8 with Figure 12, it is at once apparent that these differences are only individual variations of granular dissolution in the same kidney. Both these pictures are from the same kidney but from different levels. In Figure 8 a climping of mitochondria into larger bodies staining like mitochondria is distinctly seen. In Figure $8 a$ this has been brought out still more markedly by lengthening the bellows of the camera.

Figure 10, oil immersion, urea fed for fourteen days, shows the usual variations in the height of the cells and the difference in the mitochondrial density within one tubule. There is an early granular dissolution present, but the rodlike arrangement is still preserved: the picture is not different from the normal.

Figurc 11, high power, urea fed during the entire length of life, shows the typical bâtonné arrangement described for the normal and which is not disturbed by intense urea feeding.

Figure 12, high power, urea fed just before death, shows the early granular dissolution which occurs normally. The brush border is just faintly visible, not changed and contains a few fine granules with a mitochondrial staining reaction.

Figure 13, oil immersion, urea fed during entire lifetime, and Figure 11, oil inmersion, no urea fed at all, show primarily that the collecting segments of the tubular apparatus is partially free from mitochondria and that the few mitochondria which are present are not altered in any way or increased in number by prolonged urea feeding.

Figure 15, oil immersion, prolonged urea feeding, and Figure 16, oil immersion, 110 urea feeding. show that the glomerular apparatus is not influenced by a severe strain such as is produced by prolonged urea feeding. 


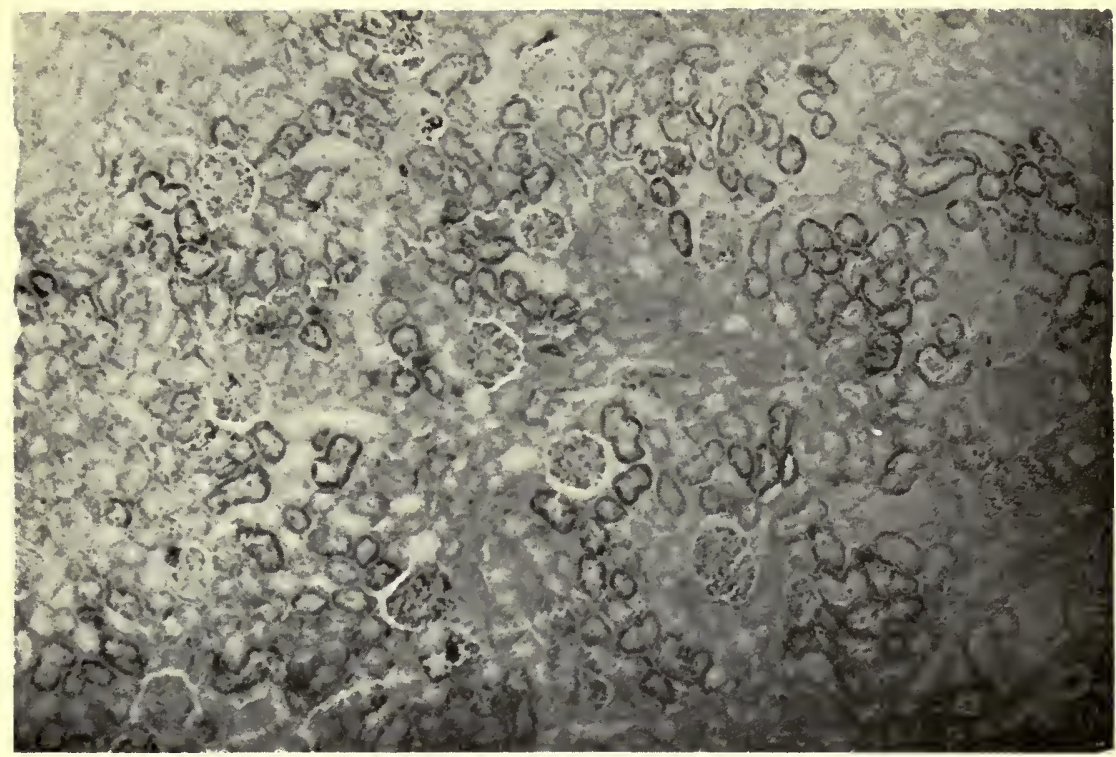

Fig. 1

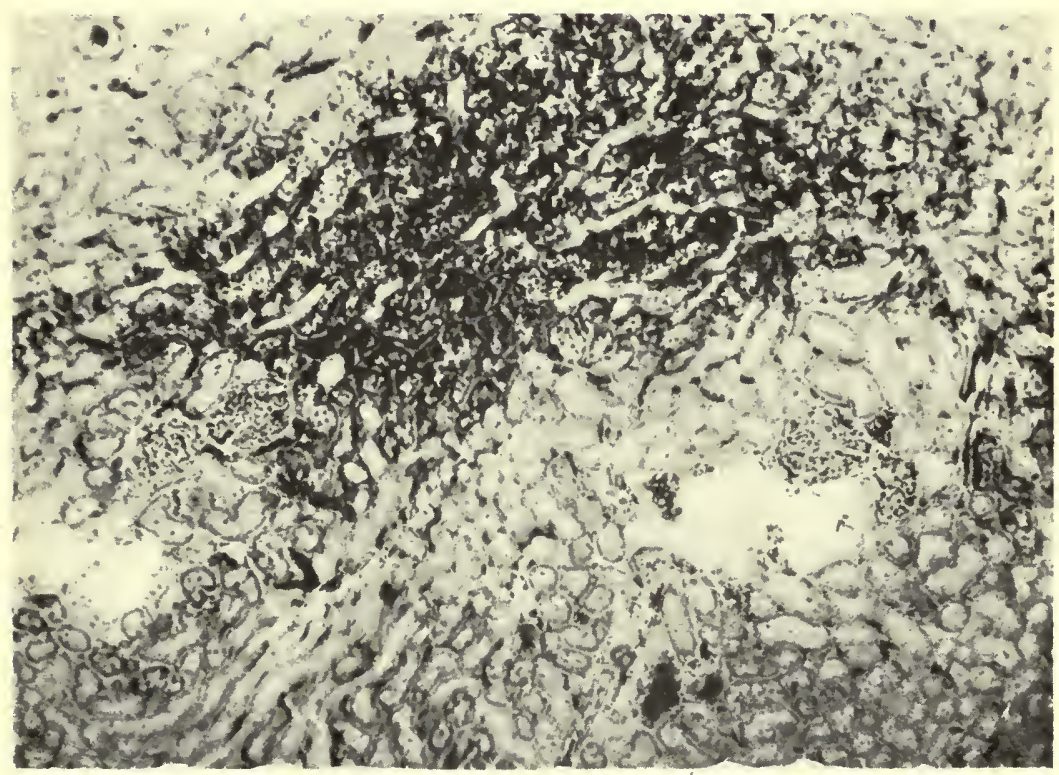

Fig. 2 




Fig. 3

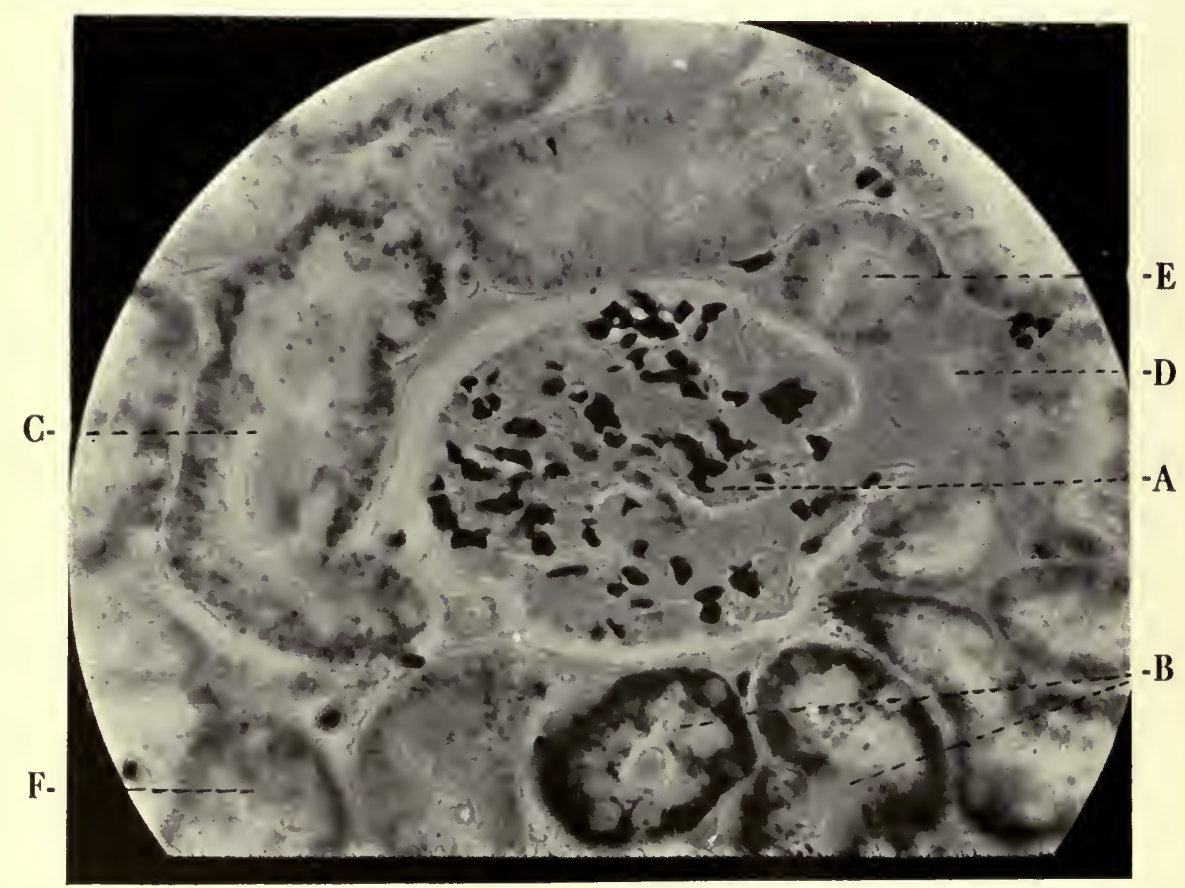

Fig. 4 


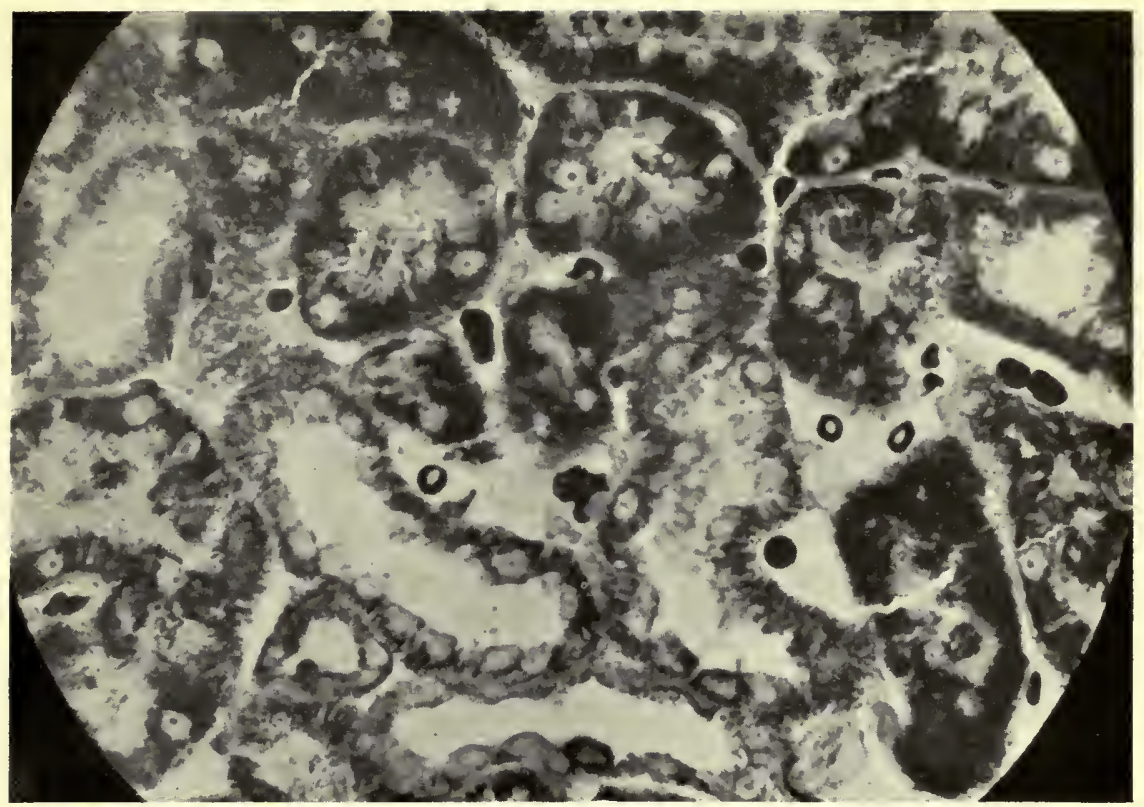

Fig. 5

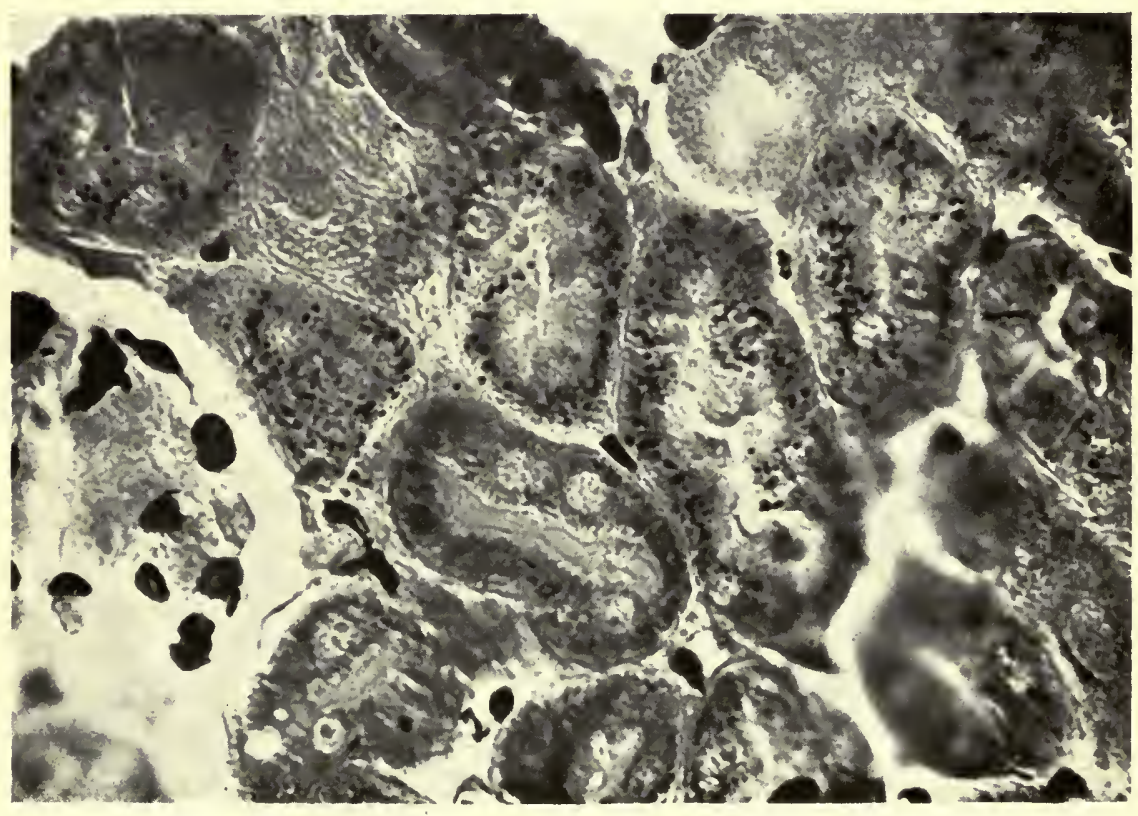

Fig. 6 


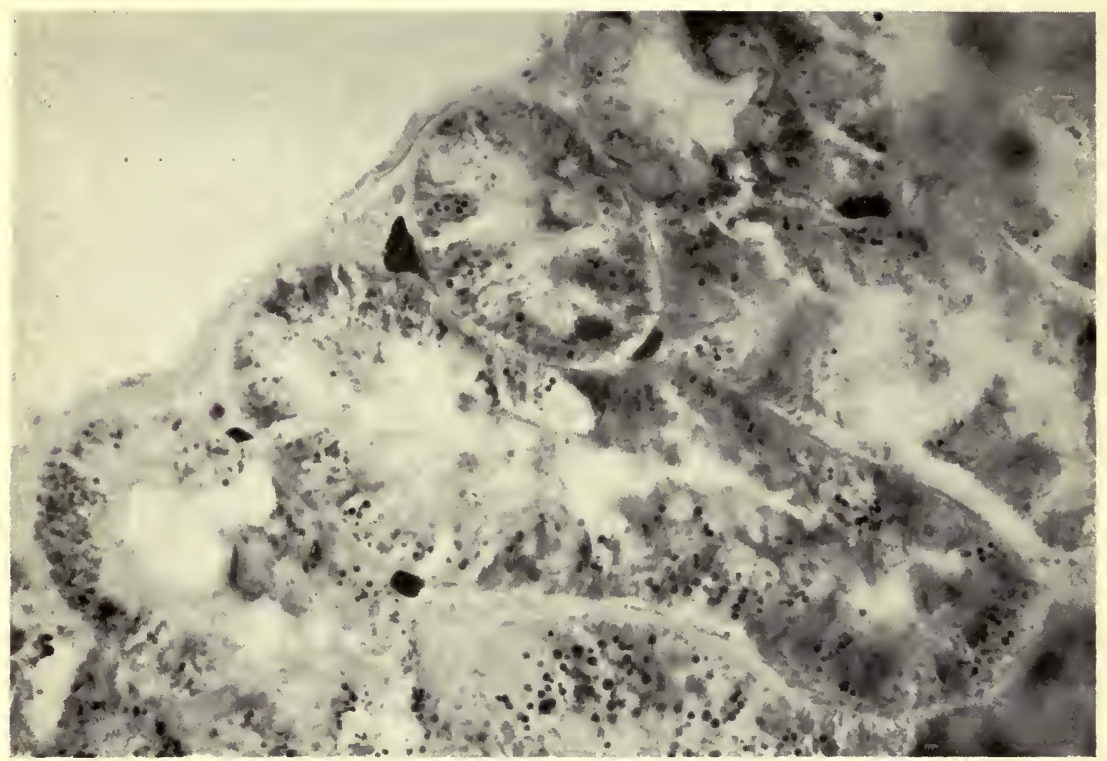

Fig. 7

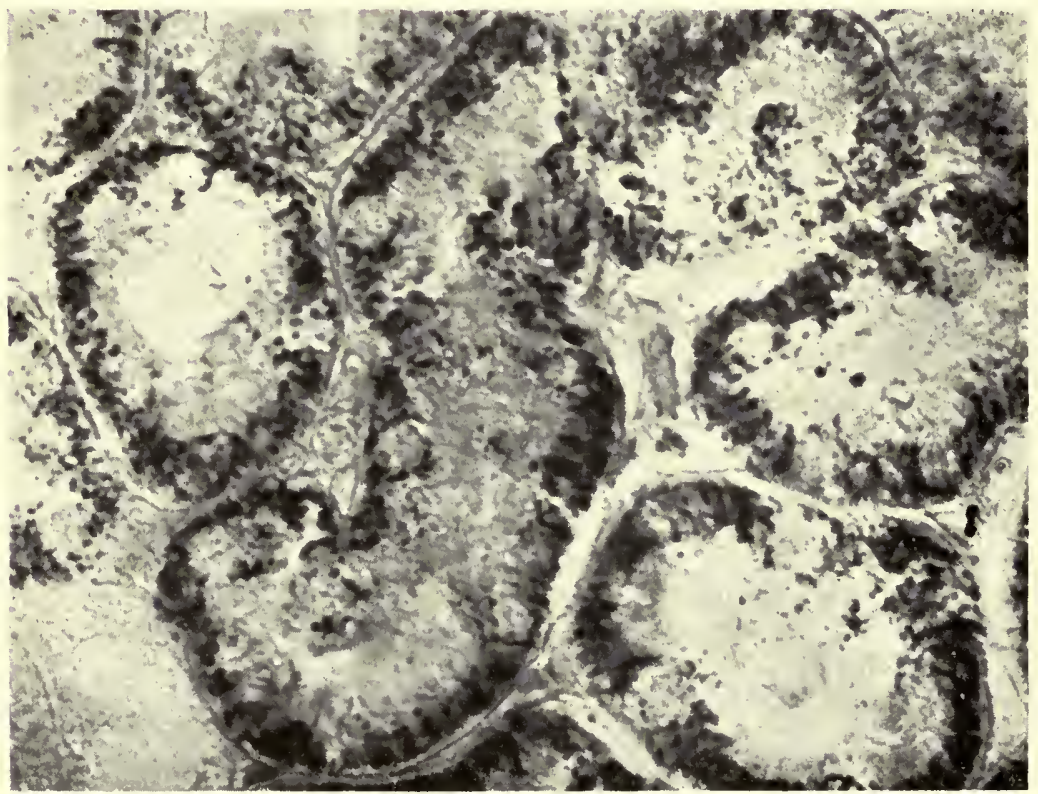

Fig. 8 


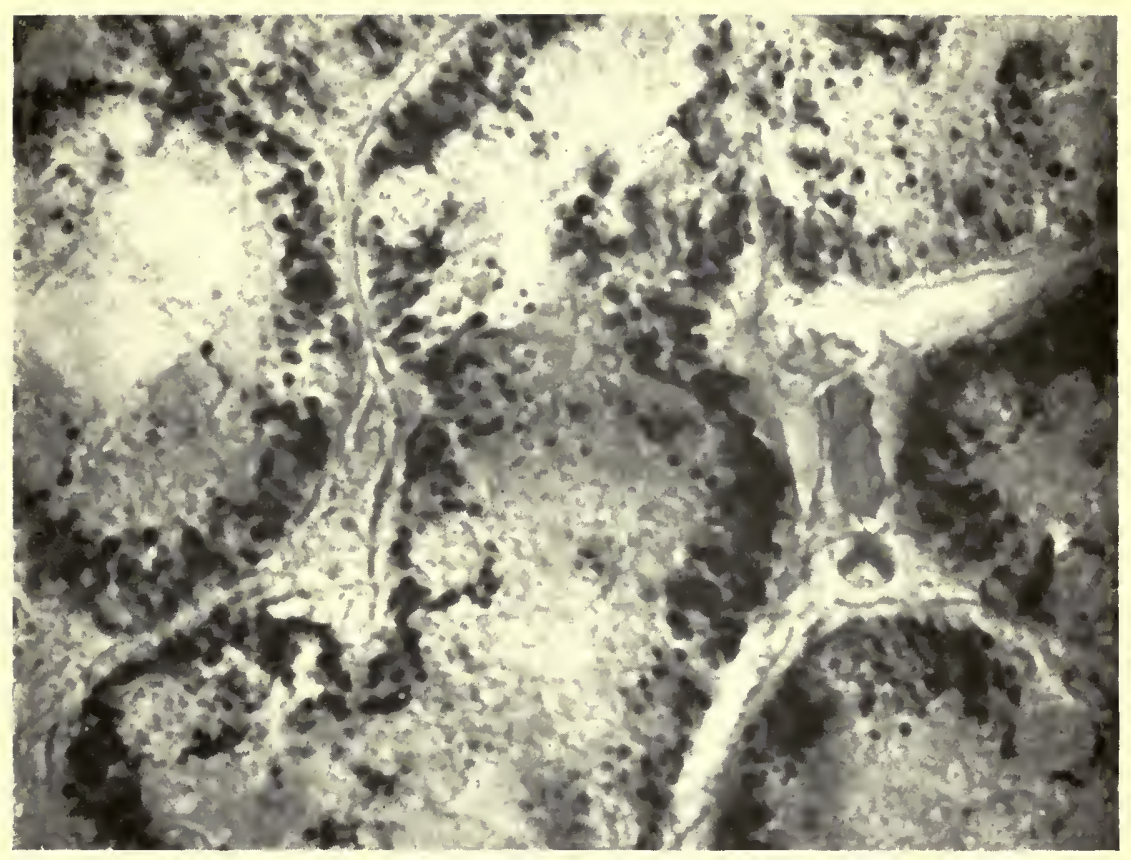

Fig. 8 a

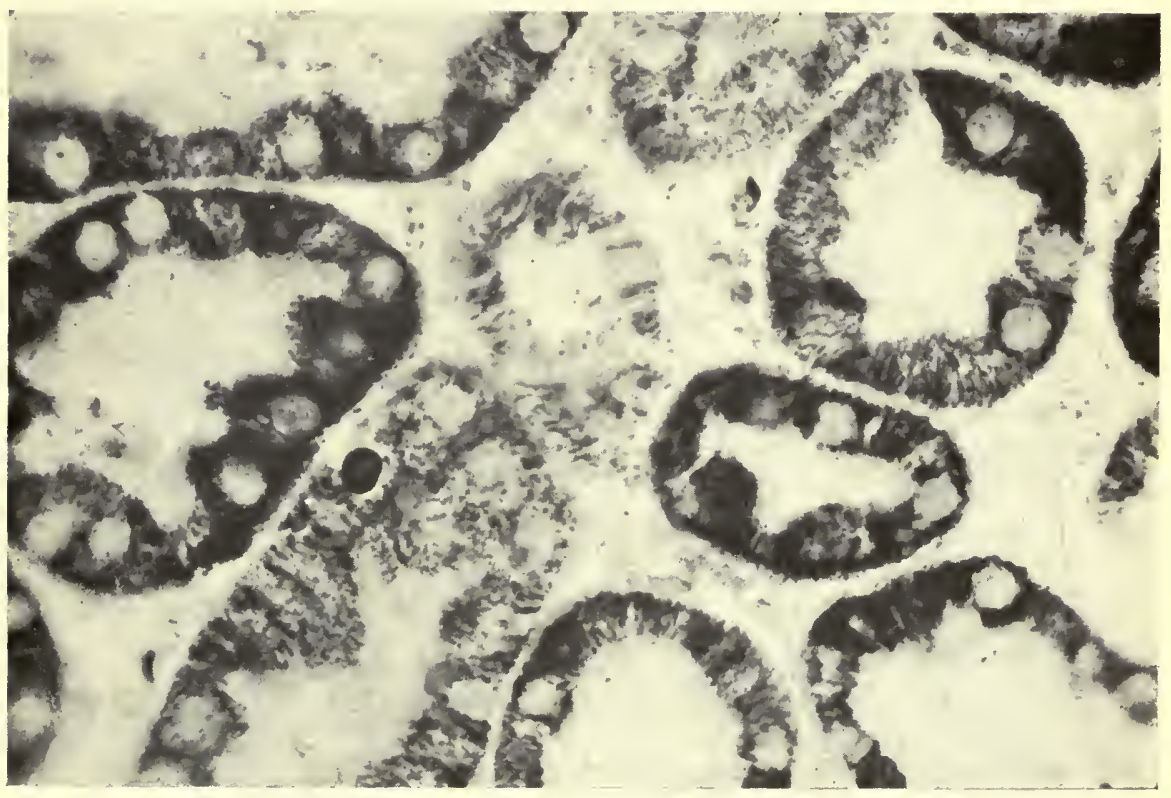




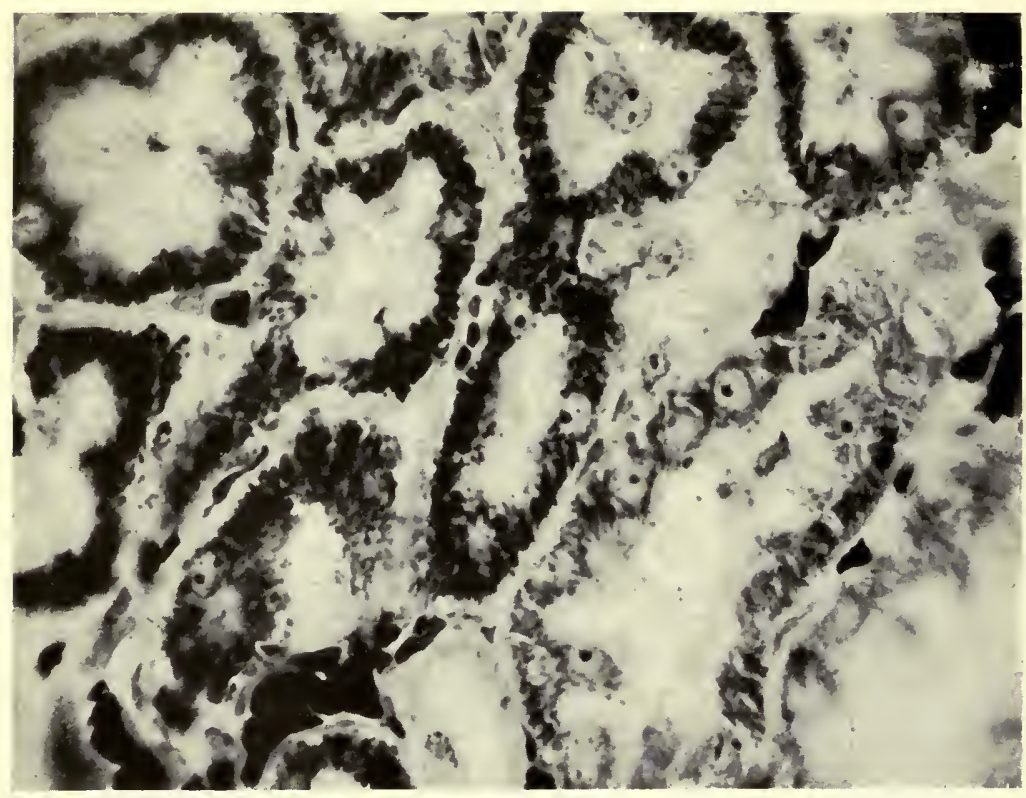

Fig. 10

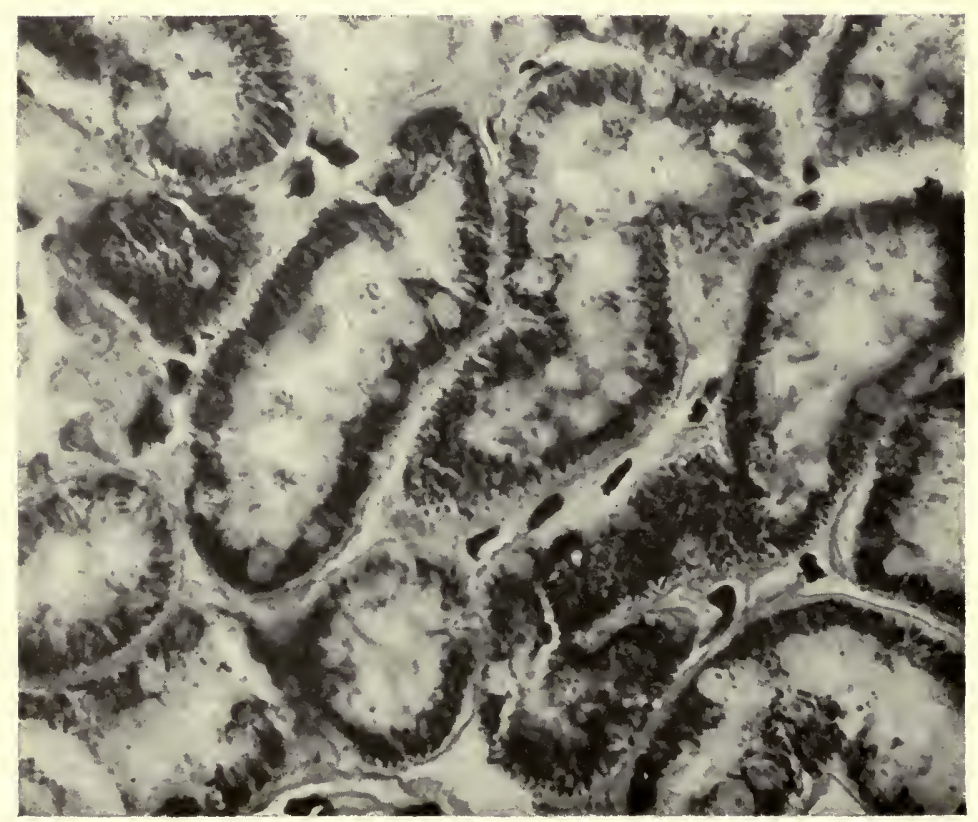

Fig. 11 




Fing. 12 

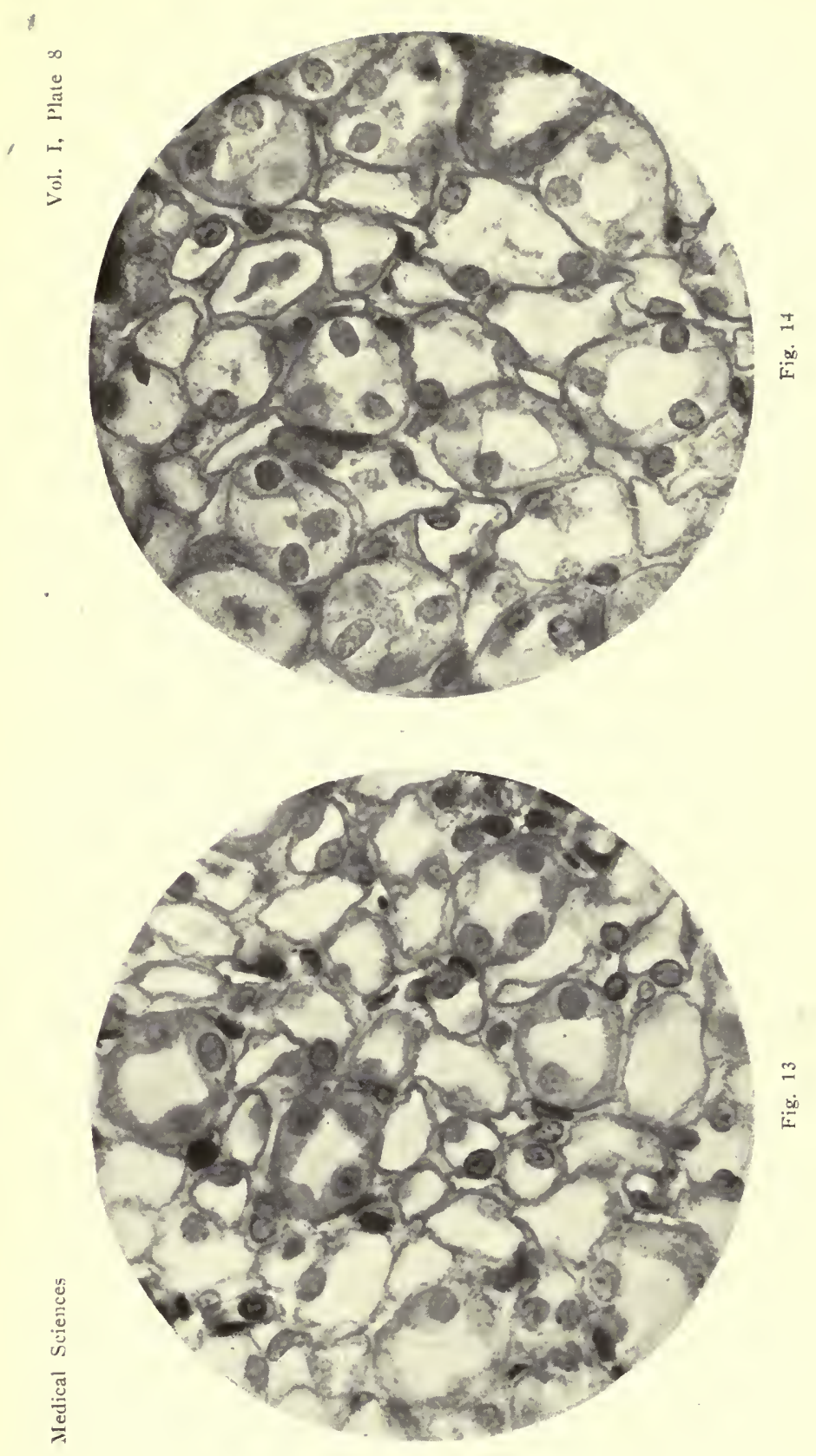

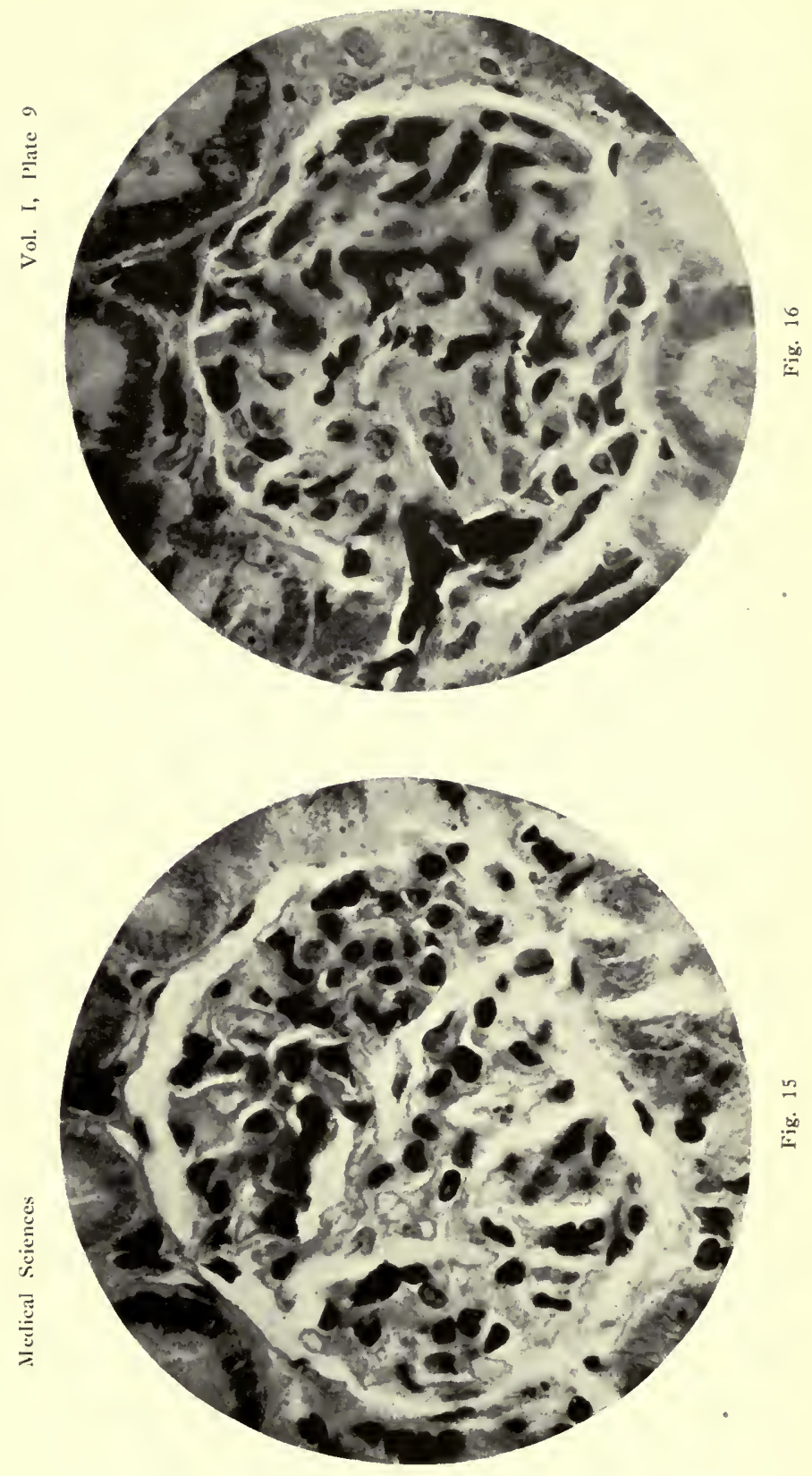



THIS BOOK IS DUE ON THE IAST DATE STAMPED BELOW

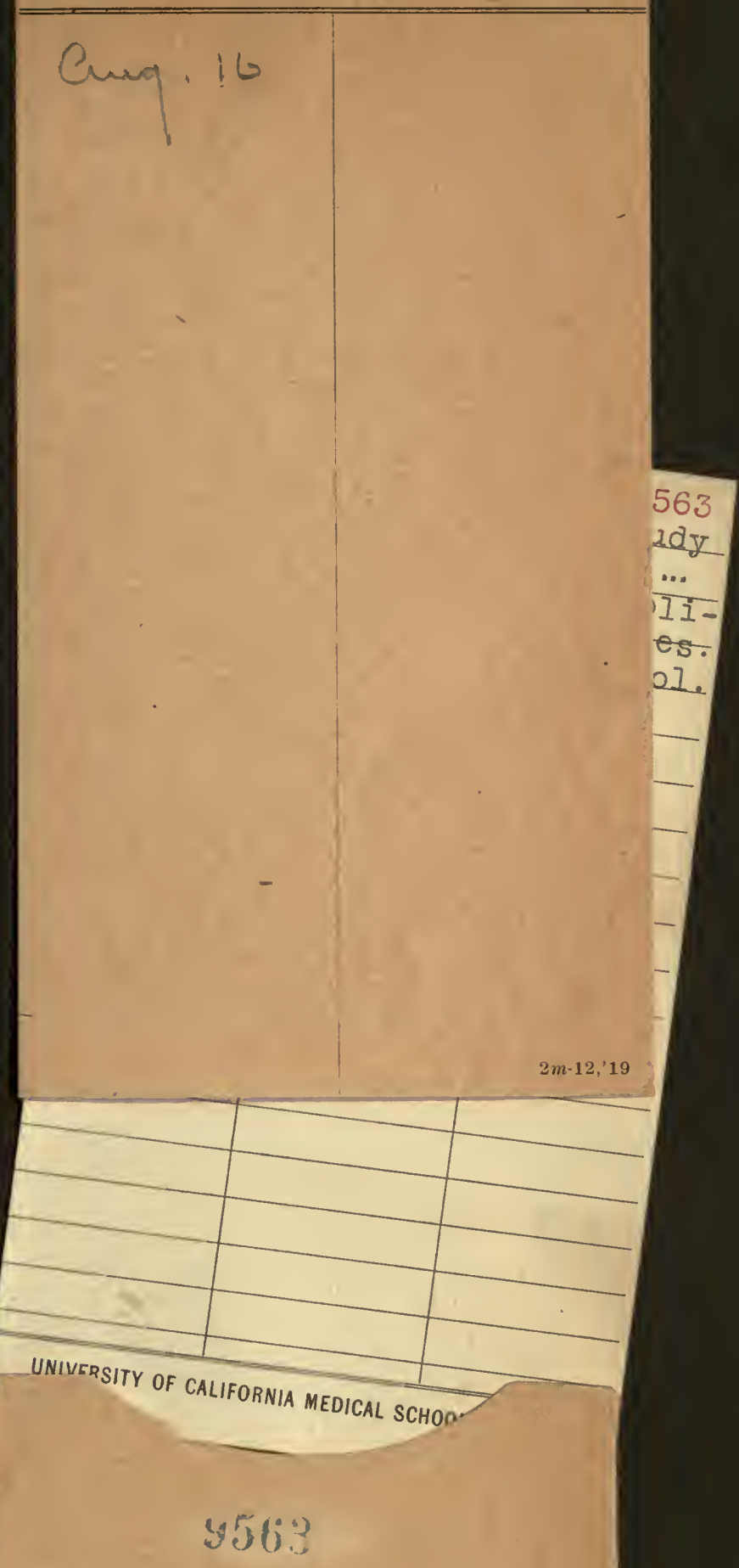

Library of the

University of California Medical School and Hospitals 
